Copyright (C) 2015 by Academic Publishing House Researcher

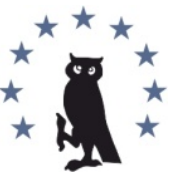

Published in the Russian Federation

European Researcher

Has been issued since 2010 .

ISSN 2219-8229

E-ISSN 2224-0136

Vol. 93, Is. 4, pp. 325-330, 2015

DOI: 10.13187/ er.2015.93.325

www.erjournal.ru

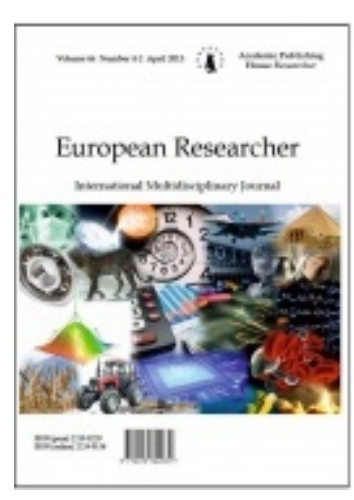

UDC 37

\title{
Effects of Learning Together, Constructive Controversy in Students' Acquisition of Knowledge and Skills in Peace Education Aspect of Social Studies
}

\author{
Rasheed Adenrele Adetoro
}

Federal College of Education, P.M.B. 2096, Abeokuta, Ogun State, Nigeria

Senior lecturer

\begin{abstract}
This study assessed the effects of two cooperative learning strategies (Learning Together and Constructive Controversy) on students' learning outcomes in Peace Education at Ogun State J unior Secondary School (JSS) Level in Nigeria. A sample size of 99 students participated in the experiment from three public J SS in the state. Using Analysis of covariance for testing two null hypotheses, it was discovered that there were no significant main effects on the knowledge $(\mathrm{F}(2,78)=1.429, \mathrm{P}>0.05)$ and conflict resolution skills $(\mathrm{F}(2,78)=0.021, \mathrm{P}>0.05)$ of the students in Peace education aspect of Social Studies. However, the Multiple Classification Analysis of the adjusted post-test mean knowledge scores (14.546) of the students treated with constructive controversy was the highest while that of the students treated with learning together (70.76) was the best in conflict resolution skills. It was therefore recommended that cooperative learning strategies (especially learning together and constructive controversy) should always be combined with the conventional method for teaching peace education aspect of social studies.
\end{abstract}

Keywords: learning together; constructive controversy; peace education; social studies.

\section{Introduction}

Peace is a necessity in every forward looking society. However, no part of the world is spared of one tension or violence. Prominent among these are the Syrian civil war, the Arab Spring in the Maghreb region (Libya, Egypt and Tunisia), the Kenya Al-Shabbab attack, the incessant Boko Haram insurgencies and kidnapping for ransom in Nigeria, the America Washington Navy yard shooting (Laub \& Masters, 2013; Hellyer, 2013; The Guardian, 2013; Reuters, 2012; Niyi, 2013; Birrell, 2013 and Dizard 2013). Indeed, the American Society for Design (2013) observed that the level of global peace has fallen from 1.96\% in 2008 to $4.9 \%$ in 2013. Salawu (2014), also observed that the years 2010 and 2011 witnessed an overall global decline in peacefulness with Iceland being the most peaceful country and Afghanistan (now Syria in 2014 ranking) the least peaceful in the world. Citing the 2012 global peace index ranking further, Salawu noted that Nigeria ranks 146 among 158 countries on world peace index. Indeed, Nigeria had been sliding in world peacefulness ranking from $118^{\text {th }}$ position (2.570) out of 162 countries in 2008 to $127^{\text {th }}$ (2.599) in $2009,131^{\text {th }}$ (2.630) in $2010,137^{\text {th }}(2.613)$ in $2011,146^{\text {th }}(2.707)$ in $2012,148^{\text {th }}(2.693)$ in $2013,151^{\text {th }}(2.710)$ in 2014 (Institute for Economics \& Peace, 2014). According to the report, the economic cost of the deteriorated 2014 peace index is equivalent of US 1,350 dollars per person.

This worrisome trend calls for new strategies to promote the culture of peace through education (Ogunyemi, 2006 \& Adetoro, 2013). Consequently, Peace Education becomes a veritable 
means of promoting knowledge, attitude and skills in non-violent behaviour and conflict resolutions. In handling conflicts amicably, UNESCO (1998) calls for "knowledge on how to resolve any dispute peacefully", Jenkins (2006) and Kester (2007) advocate for "pedagogies of engagement". Freire (1992) canvasses for "conscientization" of peoples mind to overcome oppression through transformative humanism. Ogunyemi (2006) calls for "skills in promoting peace and non-violence" while Page (2008) advocates "learning to know, learning to be, learning to do, and learning to live together" at different levels of human interactions as means of promoting peaceful coexistence and international understanding.

The challenge of teaching and learning for peace therefore throws up the challenge about methods of teaching to 'catch them young'. The contention had been between protagonists of teacher-centred and student - centred pedagogies (Adetoro, 2013). According to White (2002), "the older philosophy was you teach content and now the philosophy is, you teach students". The teaching of content has always been emphasized under lecture, discussion and illustrations as characterized by 'conventional method' (CM) of teaching in Nigeria; while the teaching of students has been the focus of values clarification, field trips, dramatization, role playing, project, laboratory works and cooperative learning strategies.

Among the most popular cooperative learning strategies that have been found to have promoted greater achievement among students are Learning Together (LT) and constructive Controversy (CC). According to J ohnson, Johnson and Stanne (2000), LT actually produced the highest effect size of between 0.82 and 1.03, closely followed by CC that produced between 0.59 and 0.91 among eight strategies of cooperative learning in a meta - analysis of 158 studies.

While acknowledging the supremacy of cooperative learning strategies adopted by Yusuf (2007) and Adeyemi (2008) as well as the Students - Team - Assisted Division (STAD) applied by Usulor (2012) and Jigsaw model used by Salako, Eze and Adu (2012) over conventional methods in teaching social studies in Nigeria; it appears the application of LT and CC for quasi experimentation on teaching of Peace Education aspect of Social Studies as focused in this study is desirable as a means of "catching them young" to promote knowledge and skills in culture of peace, non-violent behaviour and constructive controversy engagement. The theoretical framework for this study was based on social learning theory of Bandura (1976) as expantiated by Siegel (1992) that "children learn to act aggressively when they model their behaviour after violent acts of adults" (p.170). By extension therefore, it can be conjectured that children aggressive behavior can be transformed into peaceful lifestyles if constantly exposed to learning together and constructive controversy in the classroom.

\section{Hypotheses}

1) There is no significant difference in the knowledge outcomes of students in Peace Education aspects of Social Studies when taught with Learning Together, Constructive Controversy and Conventional Method.

2) There is no significant difference in conflict resolution skills of students in Peace Education aspects of Social Studies when taught with Learning Together, constructive controversy and conventional Method.

\section{Methodology}

\section{Research Design}

The study adopted pretest-posttest, control group quasi-experimental design with 3x2 factorial matrix.

\section{Sample and Sampling Technique}

The study involved a total of $99 \mathrm{~J}$ unior Secondary School II students sampled in three public secondary schools from three of the four geographical divisions in Ogun State, Nigeria. The three schools were randomly assigned to treatment (LT\&CC) and control (CM) groups. The study covered such concepts from the 2007J unior Secondary School Curriculum viz:

(i) Meaning and types of peace,

(ii) Meaning, types and examples of conflict,

(iii) Meaning, types and examples of global/international cooperation,

(iv) Ways of promoting peace, and non-violent methods of resolving conflicts. 


\section{Instrumentation}

Three instructional guides and two treatment instruments were used in the study. The Instructional guides as adopted from J ohnson \& Johnson (2007 \& 2009) were provided for the research assistants (teachers) and the students on Learning Together and Constructive Controversy mode of instructions in experimental school I \& II respectively. Equally, the Conventional Method of teaching guide was adopted for the control group by the teacher in school III. The Peace Education Achievement Test (PEAT) with 30-items was used to test the pre and post-knowledge of the students while an adapted Conflict Resolution Skill Test (CRST) of 34-items from J ohnson and LeBaron (2007) was equally used to assess the pre and post - skill levels of the students. The two instruments were subjected to expert reviews for face and content validity assessments. While a reliability coefficient of 0.63 (K21) was obtained for PEAT, an index of 0.59 was secured for CRST using Guttman split-half method.

\section{Procedure}

Initial pre-tests were conducted on the students to assess their pre-knowledge and preconflict resolution skills. Then orientations were given to both the research assistants (social studies teachers) and the students on their roles in the experiments. The LT class was to be in group of 5 each with some assigned roles as leaders, recorders etc discussing the story cards and presenting positions among themselves and later to the class on the peace and conflict concepts. The CC class was grouped into 6 with 3 serving as advocates and the other 3 as opposing each presentation with a moderator and recorder in each group. The CC groups were however to arrive at consensus to be presented to the class by each leader. The CM however were taught the concepts using the traditional mode of teacher's lesson presentation (talk-and-chalk style).

\section{Data Analysis}

The data collected were analyzed using the 14.0 version of the Statistical Package for Social Sciences (SPSS) to obtain Analysis of Covariance (ANCOVA) and Multiple Classification Analysis (MCA) on each of the two hypotheses. While the Pre-test scores served as covariates, the hypotheses were tested at 0.05 level of significance.

\section{Results}

Ho1: There is no significant main effect in the knowledge outcomes of the students in Peace Education aspect of Social Studies.

Table 1: Summary of ANCOVA of Post-Test Peace Education Knowledge Scores

\begin{tabular}{|l|r|l|r|r|}
\hline Source of Variance & \multicolumn{1}{|l|}{$\begin{array}{l}\text { Sum } \\
\text { Squares }\end{array}$} & Df & \multicolumn{1}{l|}{$\begin{array}{l}\text { Mean } \\
\text { Squares }\end{array}$} & \multicolumn{1}{l|}{ F Sig. } \\
\hline Covariates (Pretest) & 179.296 & 1 & 179.296 & 32.452 .000 \\
Intercept & 158.358 & 1 & 158.358 & 28.663 .000 \\
Treatment (Posttest) & 15.792 & 2 & 7.896 & 1.429 .246 \\
\hline
\end{tabular}

R squared $=408$ (Adjusted R squared $=-256$ ).

As can be seen in table 1, there was no significant difference in the post - test mean knowledge scores of the students in Peace Education $(F(2,78)=1.429, P>0.05)$ using LT, CC and $\mathrm{CM}$.

Table 2: Multiple Classification Analysis (MCA) of Peace Education Knowledge Scores. Grand Means = 12.976

\begin{tabular}{|l|l|l|l|l|c|c|}
\hline S/N & \multicolumn{1}{|c|}{ Treatment Group } & N & $\begin{array}{c}\text { Unadjusted } \\
\text { Deviation }\end{array}$ & Eta & $\begin{array}{c}\text { Adjusted for } \\
\text { Independent }+ \\
\text { Covariates }\end{array}$ & Beta \\
\hline 1. & Learning Together & 34 & -1.26 & & 1.02 & \\
2, & Constructive Controversy & 32 & -0.43 & 1.57 & \\
\hline
\end{tabular}




\begin{tabular}{|l|l|l|l|l|ll|l|}
\hline 3. & $\begin{array}{l}\text { Conventional Method } \\
\text { Multiple R Squared } \\
\text { Multiple R }\end{array}$ & 33 & -1.48 & .04 & 0.75 & .59 \\
.408 \\
.639
\end{tabular}

The result of the MCA in table 2 reveals that with a grand mean of 12.976, the students exposed to constructive controversy teaching method recorded the highest adjusted posttest knowledge score of 14.546 (i.e. 12.976+1.57). This was followed by the learning together group that scored 13.996 (i.e. $12.976+1.02$ ), while the students exposed to conventional method recorded the lowest adjusted post-test knowledge score of 13.726 (i.e. $12.976+0.75$ ).

Ho2: There is no significant main effect in the conflict resolution skills of the students in Peace Education aspect of Social Studies.

Table 3: Summary of ANCOVA of Post-Test Scores in Conflict Resolution Skills

\begin{tabular}{|l|r|l|r|r|r|}
\hline \multicolumn{1}{|c|}{ Source of Variance } & Sum Squares & Df & Mean Square & \multicolumn{1}{c|}{ F } & Sig. \\
\hline Covariates (Pretest) & 946.231 & 1 & 946.231 & 15.412 & .000 \\
Intercept & 3216.209 & 1 & 3216.209 & 52.384 & .000 \\
Treatment (Posttest) & 2.545 & 2 & 1.273 & .021 & .979 \\
\hline
\end{tabular}

R squared $=.319$ (Adjusted $\mathrm{R}$ squared $=.144$ )

Table 3 reveals no significant main effect of treatment on the students' conflict resolution skills scores $(\mathrm{F}(2,78)=0.021, \mathrm{P}>0.05)$. Hence, the null hypothesis $\mathrm{Ho}_{2}$ is thereby upheld.

Table 4: Multiple Classification of Conflict Resolution Skills Scores. Grand Mean $=66.060$

\begin{tabular}{|l|l|c|c|c|c|c|}
\hline S/N & \multicolumn{1}{|c|}{ Treatment Group } & N & $\begin{array}{c}\text { Unadjusted } \\
\text { Deviation }\end{array}$ & Eta & $\begin{array}{c}\text { Adjusted for } \\
\text { Independent }+ \\
\text { Covariates }\end{array}$ & Beta \\
\hline 1. & Learning Together & 34 & -1.93 & & 4.70 & \\
2, & Constructive Controversy & 32 & -3.53 & .01 & 3.20 & .00 \\
3. & Conventional Method & 33 & -4.49 & .01 & & .32 \\
& Multiple R Squared & & & & & .565 \\
\hline
\end{tabular}

The result in Table 4 shows that with a grand mean of 66.06, the students exposed to learning together method obtained the highest adjusted post-test mean conflict resolution skills score of 70.76 (i.e. $66.06+4.70$ ). This performance was followed by that of the students exposed to constructive controversy strategy who scored 69.26 (i.e. $66.06+3.20$ ) while the least score of 69.06 (i.e. $66.06+3.00$ ) was obtained by the conventional method group.

\section{Discussion}

The results of this study revealed that there was no significant main effect in the knowledge and conflict resolution skills' scores of the students in Peace Education aspect of social studies. This is in support of the older philosophy of 'teaching content' using direct instruction (White, 2002; Schug 2003; Frazee \& Ayers, 2003) and the popular cooperative learning strategies advocated by J ohnson, J ohnson and Stannne (2000).

While Schug (2003) believes that direct instruction (including conventional method) is for 'cognitive coaching', 'social scaffolding', 'authoritative learning' and 'substantive knowledge'; Frazee and Ayers (2003) are of the opinion that direct instruction serves as the background of good teaching'. To the cooperative learning advocates like J ohnson, J ohnson and Stanne (2000) however, learning together and constructive controversy are to promote group work and collective achievement in the classroom. Indeed, the mean results of this study (though not significant) confirm a little mean value increase of constructive controversy for enhancing the knowledge of the 
students in peace education and learning together for improving conflict resolution skills of the students. Nevertheless, the non-significant results are in line with the caution of Tabulawa (2013) that innovative pedagogical failure in African classrooms are more of institutional structure and practice failure due to lack of "social embeddedness" in giving attention to the peculiar social, cultural and political context of education and authority within public classrooms. According to him, the failure of pedagogical reform should not be sought solely in the inadequacies of the innovation delivery system, but in the "enveloping social structure" that involves multifarious factors like political, historical, economic, social and cultural aspects of reform. Hence, the potency equality of conventional method with learning together and constructive controversy in teaching peace education aspect of social studies as revealed in this study might have arisen from an "enveloping social structure" that needs further investigation in Nigeria's public classroom.

\section{Conclusion and Recommendations}

The outcome of this study has revealed that conventional method of teaching is by no means inferior to learning together and constructive controversy in promoting acquisition of knowledge and conflict resolution skills in peace education aspect of social studies. Rather, it is recommended that the two models of cooperative learning (LT and CC) should be combined with conventional method while teaching peace education concepts and conflict resolution skills. This is in line with Tabulawa's (2013) recommendation of "smart implementation" of pedagogical reforms. It is also recommended that teacher education programmes for pre-service teachers, seminars and workshops for current secondary school teachers, on principles and techniques of cooperative learning strategies should be organized and effectively implemented. Innovative textbooks and instructional resources are also needed to facilitate better use of cooperative learning techniques in the classroom. Furthermore, it is recommended that future researches are needed on the effect of cooperative learning strategies in social studies classroom. Equally, more investigations are recommended to be carried - out on the impact of moderator variables like gender, learning styles, classroom climate, socio-economic background, locus of control etc on cooperative learning methods.

\section{References:}

1. Adetoro, R.A. (2013). Learning Together Constructive Controversy and Learning Outcomes of Ogun State J unior Secondary School Students in Peace Education aspect of Social Studies. A Ph.D Post-Field Thesis presented to the Department of Curriculum Studies and Instruction, Olabisi Onabanjo University, Ago - Iwoye, Nigeria.

2. Adeyemi, B.A. (2008). Effects of Cooperative Learning and problem - solving strategies on junior secondary school' achievement in social studies. Education and Psychology, 6(3), 691- 708.

3. Bandura, A. (1976). Social learning and personality development. NJ : Holt, Rinehart \& Winston, Inc.

4. Barrel, I. (2013). Boko Haram Insurgency: The conflict in Northern Nigeria crying out for more attention and less violence. The Independent. Retrieved October, 1, 2013 from www.independent.co.uk/ news/ world/ africa/ nigeria.html.

5. Dizard, W. (2013). Navy Yard Shooting leaves 13 dead. Retrieved October, 2013 from www.america.aljazeera.com/articles/2013/ 9/ 16one-injured-in-usnavyshootinginwashingtonde. html

6. Frazee, B. \& Ayers, S. (2003). Garbage in garbage out: Expanding environments, constructivism and content knowledge \& K. Porter-Magee (Eds.), where did social studies go wrong? Retrieved 12th J une 2006 from http:/ / www.edexcellence.net/ doc/ contrariansfullpdf.

7. Freire, P. (1992). Pedagogy of the oppressed. The continuum publishing company.

8. Hellyer, P. (Sept. 30, 2013). Arab spring cost thousands of lives and livelihoods - for what? The National. Reprieved October 1, 2013 from www.thenational.ae/ thenationalconservation / comment/ arab-spring-cost-thousands-of-lives-and-livelihoods

9. Institute for Economics \& Peace (2014). Vision of Humanity. Retrieved J une 1, 2014 from www.visionofhumanity.org/ site/ default/ files/ 2 .

10. Jerkins, D.R. (2006). Ordered conflict resolution. Retrieved 25 $5^{\text {th }}$ March, 2010 from www.law.bepress.com/ expresso/ eps/ 1129. 
11. J ohnson, D.W. \& J ohnson, R. T. (2007). Creative constructive controversy. Intellectual challenge in the classroom ( $4^{\text {th }} \mathrm{Ed}$ ). Edina, M. N.: Interaction Book Company.

12. J ohnson, D.W. \&J ohnson, R. T. (2009). Learning together. In S. Sharan (Ed.), Westport, C. T. Greenwood Press.

13. J ohnson, D.W.; J ohnson, R. T. \& Stanne, M. B. (2000). Cooperative learning methods: A meta analysis. Retrieved $14^{\text {th }}$ March 2010 from mhtml: file: $11 D$ :! constructive $\% 20$ controversy \% 20 method 4 mht.mht-overview\%20of.

14. J ohnson, L.M. \& LeBaron, M. (2007). Conflict tactics in a mediation setting. The Peace and Conflict review, (2) 2. Retrieved 10 ${ }^{\text {th }}$ August, 2009 from PDF version of University for Peace from www.goggle.com.

15. Kester, K. (2007). Peace education: Experience and storytelling as living education. the Peace and Conflict Review, (2) 2, Retrieved 10 th August 2009 from the PDF version for Peace from www.goggle.com.

16. Laub, Z.\&Masters, J. (2013). Syria's crisis and the global response. Backgrounder. Retrieved October 1, 2013 from www.cfr.org/ syria/ syrias-crisis-global-response/ P.28402.

17. Niyi, O. (2013). Yobe attack: Death toll rises to 78. Retrieved October 1, 2013 from www.informationng.com/ 2013/09/yobe-attack-death-toll-rises-to-78.html.

18. Ogunyemi, B. (2006). Curriculum imperative for teacher preparation in peace and human rights education: The Nigerian case. In O. A. Oyedeji, B. Ogunyemi (Eds). Perspectives in Nigerian education: Issues of the new millennium pp. 225-237). Ibadan: Bash Moses Publishers.

19. Page, J.S. (2008). Peace education: Exploring ethnical and philosophical foundations. Charlottesville: Information Age Publishing.

20. Reuters, T. (2012). Timeline on ethnic and religious unrest in Nigeria. Retrieved 12 March, 2013 from http:// www.reuters.com/ article/ 2012/ 01/24nigeria-sect-violence.

21. Salako, E.C.; Eze, I.R. \& Adu, E.O. (2012). Effects of cooperative learning on junior secondary school students' knowledge and attitudes to multicultural education concepts in social studies. Discovery science, 2(4), 15-18. Retrieved 29th June 2013 from www.discovery. org.in/ ds.htm

22. Salawu, K.A. (2014). Towards achieving peace, national unity and sustainable political stability in Nigeria. Being a lead paper presented at the 1st National Conference Organized by Centre for Continuing Education and Consultancy (CECECO), Federal College of Education on 27th May, 2014).

23. Schug, M.C. (2003). Teacher - centred instruction: The Rodney Dangerfield of social studies. In J . Learning, L. Ellington \& K. Porter-Magee (Eds). Where di social studies go wrong? Retrieved $12^{\text {th }} \mathrm{J}$ une 2006 from http:/ / www.edexcellence.net/ doc/ contrariansfullpdf.

24. Siegel, L. (1992). Criminology. Saint Paul, Mien: West Publishing Company.

25. Tabulawa, R. (2013). Teaching and learning in context: Why pedagogical reforms fail in Sub-Saharan Africa. Dakar: Codestria.

26. The American Society for Design (2013). 2013 Global Peace Education Index-Building Pillars of Peace. Retrieved 2nd August from www.theasideblog.blogspot.com/2013/06/2013-globalpeace-index-building.html.

27. The Guardian (Sept. 21, 2013). Gun attack on Kenya shopping centre kills at least 25. Retrieved October 1, 2013 from www.theguardian.com/world/2013/sept/21/gunman-kenyashopping-centre-nairobi.

28. UNESCO (1998). Promoting a culture of peace in higher education in the twenty first century: Vision and action. Paris: UNESCO.

29. Usuolor, B.E. (2012). Effects of cooperative learning instructional strategy on junior secondary school students' achievement in social studies. Nigerian J ournal of Social Studies and Civic Education, 2(1), 1-9.

30. White, T. (2002). Towards futuristic school (PB6). Baltimoe: Sun.

31. Yusuf, A. (2007). Effects of cooperative instructional strategy on students' performance in social studies. Retrieved 25th March, 2009 from www.unilorin.edu.ng. 